\title{
Immigration Policies and Group Identity: How Immigrant Laws Affect Linked Fate among U.S. Latino Populations
}

\author{
Edward D. Vargas
}

University of Wisconsin-Madison

Gabriel R. Sanchez

University of New Mexico

Juan A. Valdez Jr.

University of Notre Dame

\begin{abstract}
Immigrant sentiment, measured by the number of state laws enacted to curb the flow of undocumented immigration or expand rights to immigrants, have been on a steady incline since September 11, 2001. Despite the increased attention to unauthorized immigration, little research has examined how immigrant policies are affecting group identity (i.e., linked fate). Linked fate is a form of collective group identity that develops when a group of people experience discrimination and marginalization. Using a unique database that merges the 2012 Collaborative Multiracial Post-Election Survey $(n=934$ Latinos) with the sum of state-level immigration policies enacted from 2005 to 2012, this study is the first to examine the direct relationship between immigrant climate and linked fate. Results from our multinomial logistic regressions indicate that the linked fate among Latinos increases as the number of punitive immigration laws in a state increases, controlling for a vector of control variables. Consistent with our theory regarding differential impact, our findings also suggest that immigration
\end{abstract}

Address correspondence and reprint requests to: Edward D. Vargas, Center for Women's Health and Health Disparities Research, University of Wisconsin-Madison, 310 N. Midvale Blvd, Suite 201, 1180 Observatory Drive, RM 3467, Madison, WI 53705. E-mail: edward.vargas@gmail.com 
laws have a more pronounced influence on the linked fate of foreign-born Latinos.

Keywords: Linked Fate, Group Identity, Immigration Policy, Latino Populations.

\section{INTRODUCTION}

"A law enforcement official or agency of this state or a county, city, town, or other political subdivision of this state may not solely consider race, color, or national origin in implementing the requirements of this subsection except to the extent permitted by the United States or Arizona Constitution."

- Original Language of Arizona S.B. 1070 as Signed by Arizona Governor Brewer, April 23, 2010.

That undocumented immigrants in the United States are framed as economic burdens, heinous criminals, and drug traffickers is no secret. Sponsors of anti-immigrant legislation often resort to negative stereotypical accounts of undocumented communities in the drafting of such legislation. At first glance, anti-immigrant legislation, such as Arizona S.B. 1070 and Alabama H.B. 56 are often coded under "colorblind" language so as to justify the legislation under economic and legal concerns-rather than racial frames (Johnson 2012; Omi and Winant 2014). However, upon closer inspection into the legislative process and into the language of the original bills, the racial motivations behind laws such as Arizona S.B. 1070 become self-evident. For instance, the original clause in Arizona S.B. 1070 contains that law enforcement may not solely "consider race, color, or national origin" in the implementation of the bill-coded language that intrinsically green-lights racial profiling by law enforcement despite the assertions of the original drafters (Johnson 2012; Selden, Pace, and Nunn-Gilman 2011). Within the week, S.B. 1070 was quickly amended with Arizona H.B. 2162 that stripped the word "solely" from the clause, while simultaneously expanding the scope of the law with additional language as to what constituted "lawful contact" (Selden, Pace, and Nunn-Gilman 2011). Finally, the rhetoric utilized by AL legislators in their testimonies for the passage of Alabama H.B. 56 exposed how legislators frequently conflated Latinos with "illegal" immigrants, indicating the racialization of undocumented immigrants and Latinos alike (Central Alabama Fair Housing Center, et al. v. Julie Magee, et al. 2011). 
Similar in nature to Arizona S.B. 1070, Alabama's H.B. 56 requires police officers in the state to ascertain the immigration status of people stopped, detained or arrested, and prohibits undocumented immigrants from receiving any public benefits at the state or local level, prevents undocumented immigrant students from attending public institutions of higher education, and requires public elementary and secondary school officials to ascertain whether students are undocumented. ${ }^{1}$ The recent policy climate has not been restricted to $\mathrm{AZ}$ and $\mathrm{AL}$. In fact, despite multiple challenges to the constitutionality of S.B. 1070 and H.B. 56, other states have rapidly introduced and adopted nearly identical bills as a method to curb the influx of immigrants into their communities; ultimately representing the overarching anti-immigrant climate currently present throughout the United States.

There were record numbers of anti-immigrant policies passed at the state and local levels during the first decade of the new millennium driven by a combination of demographic changes and political opportunism among Republican legislators (Chavez and Provine 2009; Gulasekaram and Ramakrishnan 2013, 2015; Hopkins 2010; Monogan 2013; Wallace 2014), a strong indicator of the anti-immigrant sentiment that emerged in reaction to the diversity fueled by external migration. Although the rise in policy action directed at the foreign-born population throughout the last two decades and has been well noted by the academicians and political pundits, less is known about the consequences of the anti-immigrant sociopolitical climate on the immigrant population. We attempt to shed some light on this subject by exploring the relationship between the rise of punitive immigration laws and the group identity of the Latino population expressed through linked fate. More specifically, the question we explore is how immigration policies affect linked fate among a 2012 nationally representative study of Latino registered voters.

This is an important line of inquiry given the propensity for linked fate to influence the political behavior of racial and ethnic populations, including Latinos. Scholars have noted that Latinos have difficulty establishing a collective group identity due to the disparate and complex nature of their immigration histories (Beltran 2010; Fraga et al. 2006a). However, the development of linked fate among Latinos as a result of experiences of discrimination and marginalization associated with the rise of anti-immigrant (and anti-Latino) sentiments remains under-studied. We address this limitation in the literature by combining two appropriate datasets: state-level immigration data from the National Conference of State Legislatures from 2005 to 2012 (Ybarra, Sanchez, and Sanchez 2016), 
and a 2012 Post-Election Survey collected by Knowledge Networks that includes a measure of linked fate and several key control variables. Through this unique design, this research is important as it analyzes the effects of immigration policies on Latino group identity. This study adds to the literature by establishing a direct link between public policy, in this case the recent surge of anti-immigrant laws, and Latino linked fate. In short, we find that the rise in punitive immigration laws is leading to a significant increase in Latino perceptions of common or linked fate. Conversely, our dataset also allows for an analysis of how laws that are less punitive, and that may benefit immigrants, affect group identity, if at all.

\section{The Punitive Nature of Contemporary Immigration Policies}

Throughout U.S. history, terms with negative connotations such as "illegal alien," "illegal immigrant," and "undocumented workers" have been consistently attributed to Latinos who crossed the border and reside in the United States (Vélez et al. 2008). The use of these terms socially stratifies Latino immigrants by incorporating them into the labor market but denying them membership into U.S. society (Vélez et al. 2008). The antiimmigrant sentiment, climate, and hostility may be more prominent in historical gateway states such as CA and AZ, but anti-immigrant sentiment has been increasingly adopted in new immigrant destination states such as AL, GA, NC, and SC. The arrival of Latinos has brought the histories of racism, labor exploitation, and hostility into national dialogs concerning immigration (Winders 2011). For instance, Operation Hold the Line in 1993 and Operation Gatekeeper in 1994 increased the number of border patrol agents in the historical gateway states of CA and TX (Magaña 2013). Moreover, in his 1994 campaign, California Governor Wilson successfully utilized a campaign strategy designed to fuel antiimmigrant and anti-Latino sentiment (Perreira 2011). That same year, voters approved an anti-immigrant initiative, California Proposition 187, which denied undocumented immigrants and their children several state public services such as welfare benefits, non-emergency health care, and public education (Perreira 2011). In 1996, Congress passed the Illegal Immigration Reform and Immigrant Responsibility Act (IIRA), which broadened restrictions on legal immigrants and their access to federal, state, and local benefits such as welfare and social security (Magaña 2013). 
Congress not only increased immigration-related criminal penalties, but also added Section 287(g) to the Immigration and Nationality Act (Magaña 2013). Section 287(g) authorizes local law enforcement to enforce immigration policies if they have had the proper training. While the provision does specify that an official may not apprehend an individual based on their skin color or perception that the individual may be an illegal immigrant, a 2009 report by the U.S. Government Accountability Office found officers deporting unauthorized immigrants for minor violations (Magaña 2013).

Taking advantage of the growing nativist sentiment and economic anxiety among Americans, H.R. 4437, more famously known as the Sensenbrenner Bill, was introduced in 2005. Formally named as the "Border Protection, Antiterrorism, and Illegal Immigration Control Act of 2005," the Sensenbrenner Bill proposed to make the presence of a foreigner in the United States without documentation an aggravated felony, along with assisting undocumented immigrants in residing in the country (Vélez et al. 2008). While the Sensenbrenner Bill was killed in the Senate, it was however, a harbinger of the 2006 border-wall. In 2006, Congress passed the Secure Fence Act, which proposed to secure approximately 700 miles of the border between the United States and Mexico by constructing a physical barrier, with state-of-the-art surveillance, designed specifically to keep immigrants out (Magaña 2013).

American nativism became further revived after the 9/11 attacks and the passing of the USA Patriot Act (Galindo 2011). The Patriot Act expanded the jurisdiction of law enforcement agencies and gave government officials the authority to access personal records and sensitive information to better combat the threat of terrorism (Vélez et al. 2008). This increased the visibility of undocumented immigrants and contributed to a surge in anti-immigrant sentiment and the establishment of anti-immigrant vigilante groups such as the Minuteman Civil Defense Corps and the Minuteman Project (Magaña 2013; Vélez et al. 2008).

Reflective of a high increase in state focus on immigration policy over the last decade, AZ passed a series of anti-immigrant state initiatives in the early 2000s (Magaña 2013). For instance, voters approved a proposition that made English the official language of the state and required most government activities (with a few exceptions) to be conducted in English (Magaña 2013). Under this proposition, teachers can be penalized if they are caught teaching in Spanish. Furthermore, voters also passed Proposition 300 in 2006, which restricts in-state tuition, grants, 
scholarships, and financial aid to students with legal status only (Magaña 2013). A non-traditional gateway state, AL passed the extreme antiimmigrant law HB 56 in 2011. Alabama HB 56 requires state officers to investigate the immigration status of anyone who is stopped or detained. It also prohibits unauthorized immigrants from receiving public state benefits, including restricting access to public colleges and universities for unauthorized students. These anti-immigrant laws are signals of the greater trend in state anti-immigrant policy activity, as the number of proposed immigration bills increased from 300 in 2005 to over 1,500 in 2009 (NCLS 2011). As for enacted laws, 39 laws were enacted in 2005, and in 2009 that number increased to 200 (NCLS 2011).

American nativism expresses itself in other "restrictist" state laws such as California's Proposition 187, the CA, AZ, and MA anti-bilingual education initiatives, and the 18 "English as the official language" state initiatives (Galindo 2011). These laws socially stratify immigrants by prohibiting or restricting their access to societal benefits and their full participation in civic/political life (Galindo 2011). Anti-immigrant sentiment, attitudes, and policies make distinctions between true members of society and foreigners/aliens (Galindo and Vigil 2006). Consequently, S.B. 1070 and H.B. 56, along with other anti-immigrant laws, have led to widespread organizations and protests, fighting for immigrants' rights and a comprehensive immigration reform (De Casanova 2012).

The nature of the debates surrounding these laws suggests that there is reason to suspect that these punitive policies may have an impact on ethnic identity for Latinos. For example, the framing of immigrants as criminals and economic parasites has also contributed to the anti-immigrant climate (Winders 2011) and likely cues a sense of anti-Latino views, even for nonimmigrant Latinos. Furthermore, immigrants and Latinos more generally have been framed as dangers to neighborhoods and public safety during this period of heightened immigration policy action (Winders 2011). This is reinforced by perceptions that Hispanic immigrants are a transient workforce that lacks long-standing employment (Brettell and Nibbs 2011; Bump 2005), and therefore, do not require integration into communities and access to social services (Bump 2005). While research has yet to link immigration laws with ethnic identity directly, the 1990s antiimmigrant climate in the nation helped spark a cohesive identity among Latinos and resulted in higher naturalizations than the previous decade (Félix 2008).

More recently, widespread immigrant demonstrations with unprecedented numbers of immigrants took place in 2006 to protest against the 
Sensenbrenner Bill (De Casanova 2012; Wallace 2014). The strong antiimmigrant nature of the Sensenbrenner bill brought together many Latinos of different backgrounds, ethnicities, and nationalities (De Casanova 2012). These Latino movements are based on finding connections and producing sameness where there are clear differences of race and nationality (Winders 2011). Large-scale immigration policies play a vital role in the formation of Latino identity, since immigrants form strategies to participate in the political process, and in doing so construct new forms of citizenship to legitimize their right to participate in American society (Torres and Wicks 2013). Interestingly research finds, concerning the motivation for our theory that the laws will have an effect on Latino linked fate regardless of immigration status; research finds that both Latino citizens and non-citizens often participated in political activities relating to immigration reforms (De Casanova 2012). More to the point, Latinos participating in the 2006 protests against the Sensenbrenner Bill justified their actions as those of a collective Latino immigrant identity and a panethnic group identity (De Casanova 2012). Furthermore, research showed that while exposure to the 2006 rallies increased negative views of immigrants among non-Latinos, the marches led to more positive attitudes toward Mexican immigrants among Latinos (Marks, Nuno, and Sanchez 2009).

While it seems likely that the high volume and nature of these laws and the resulting counter movement would influence group identity, scholars have yet to explore the impact of punitive laws on the development of Latino ethnic identity. We attempt to fill this gap in the literature by exploring the relationship between punitive immigration laws and Latino linked fate. We approach our analysis from the standpoint that immigration laws, and particularly those that are punitive toward immigrants, will have a positive impact on linked fate among Latinos overall, and especially among those who are foreign-born. This theory is grounded in the work of those who have explored the formation of collective identity among Latino immigrants (Chavez 2008; Massey and Sanchez 2010; Wiley, Figueroa, and Lauricella 2014). For example, Massey and Sanchez (2010) illustrate through in-depth interviews that immigrants from Latin America formulate a Latino identity almost immediately after arriving to the United States largely due to a hostile environment that includes punitive policies. This is supported by the work of Wiley, Figueroa, and Lauricella (2014) who argue that Latino immigrants have become aware of their perceived unrecognized place in society by the large number of deportations and restrictionist laws. Recent survey data 
from Latino Decisions have provided direct evidence that the Latino population, not just immigrants, are conscious of the rise of deportations and anti-immigrant climate. In fact, a recent survey conducted by that firm found that $36 \%$ of Latino immigrants know someone personally who has been detained or deported, with an astonishing $78 \%$ of respondents believing that there is an anti-Hispanic/immigrant climate in the United States. ${ }^{2}$ We believe that this work has laid the groundwork for our analysis that more directly assesses the relationship between immigration policy and Latino linked fate.

\section{Politicized Group Identity}

Social identity has remained a relevant area of research in the social sciences for some time. For instance, previous investigations of American identity have examined the subjective meaning of being an "American" and the implications of this aspect of political identity (Huddy 2001). These examinations identified several key American values that define an American sense of political identity, such as equality, individualism, and nativism (Huddy 2001). In addition, studies on social identity address the kinds of issues relevant to political science, political psychology, and social psychology, such as intergroup conflict, the effects of low group status, the conditions under which low group status emerges, and the factors that promote the self-categorization of oneself and others into groups (Hackel, Looser, and Van Bavel 2014; Huddy 2001). This research highlights the importance of group membership in shaping political behaviors (Conover 1988; Huddy 2001; Miller et al. 1981). In addition to political identity more generally, group identity within minority populations has also remained an important area of research in the social sciences. Similar to strong levels of group identity among white Americans, positive political implications and outcomes among racial and ethnic groups are attributed to strong levels of group identity (see McClain et al. 2009).

Research suggests that ethnic-based rejection, discrimination, or marginalization results in stronger in-group identity, which in turn results in increased levels of political participation (Branscombe, Schmitt, and Harvey 1999; Dawson 1994; Sanchez 2006). The powerful role of perceived rejection and discrimination in the formation of group identity is important to our theory, as research has shown the current anti-immigrant climate to yield a sense of perceived threat among Latinos. For example, 
Chavez (2008) finds that Latinos, and particularly Latino youth, view themselves as a threat to the dominant society with Latinos being racialized during this anti-immigrant climate in which they are living. This is reinforced by the work of others who have found a perception of threat driven by anti-immigrant sentiment to lead to political mobilization, civic engagement, and potentially a heightened sense of group identity (Barreto et al. 2009; Ramirez 2013; Zepeda-Millan 2014). Most closely aligned with our work here, Zepeda-Millan (2014) finds that Latino participation in the 2006 protests in New York was at least somewhat explained by how the proposed legislation was perceived to harm them individually. This notion of perceived threat and reaction to legislation provides support for our theory regarding a relationship between state immigration laws and linked fate among Latinos.

Research also specifies that Latinos with a strong sense of group identity are more likely to participate in political activities that directly affect the status of their community, such as attending demonstrations on issues related to Latinos or donating money to Latino candidates (Sanchez 2006). Recent studies propose that group identity can help explain high participation rates among minority and disadvantaged groups (Leighley 2001; Olson 1965; Verba and Nie 1972).

One form of group identity of particular interest to political scientists is linked fate, which is developed when individuals recognize their status as being part of a marginalized or deprived group (Dawson 1994; Garcia 2003; Sanchez 2006). The concept of linked fate is best explained as a dimension of group identity that develops when a particular racial or ethnic group experiences a shared history of marginalization or discrimination. Specifically, linked fate is the belief that an individual's fate is connected with those of their racial or ethnic group (Dawson 1994). An individual with a strong sense of linked fate may choose to place the needs of his ethnic group or community above his or her own self-interest. This suggests that the individual believes his or her life chances will be directly affected by resolving the problems faced by their ethnic or racial group (Sanchez and Masuoka 2010). Therefore, individuals with a strong sense of linked fate also have a strong connection with their ethnic or racial group politically (Sanchez and Masuoka 2010).

Dawson (1994) provides a strong theory of linked fate within the context of African-American politics. Dawson's (1994) theory implies that individual political interests are replaced by group interests for Blacks due to the historic and continued racial discrimination directed toward the group. The theory, drawn from social cognitive psychology, stresses group identity, 
group dependence, and group subordination (Conover 1984; Tajfel 1981). Moreover, Dawson's theory (1994) explains that individual rational choice is not based upon maximizing individual gain but upon the group's overall position in the social structure (Dawson 1994; Przeworski 1985). Linked fate has been found to be a major factor in explaining the higher than predicted political participation rates of African Americans when looking solely at socioeconomic status (Dawson 1994; Miller et al. 1981; Tate 1993) and in explaining the relative cohesive political behavior among African Americans (Dawson 1994).

Until recently, research on linked fate was narrowly focused on the experiences of African Americans; however, recent research has shifted to identifying linked fate within panethnic communities as well. For instance, research reveals that linked fate is not only relevant within the Asian-American community, but also increases their political participation in ways similar to what has been found for Blacks (Lien, Conway, and Wong 2004; Masuoka 2006). Moreover, in a post-9/11 era, research finds significant levels of linked fate within the Muslim American populations as the resurgence of American nativism has provoked anti-foreigner sentiment in the United States (Barreto, Masuoka, and Sanchez 2008). More directly tied to our study, analysis of the Latino National Survey indicates that a large segment of the Latino population perceives that their individual fate is tied to that of other Latinos, including the status of their national origin group (Sanchez and Masuoka 2010).

The Sanchez and Masuoka (2010) article is of particular relevance to our theory, as the authors attempt to identify factors that contribute to this form of politicized identity. Their findings suggest that Latino linked fate appears to be based on social integration and the degree of marginalization derived from socioeconomic status and immigration experiences (Sanchez and Masuoka 2010). Through analyzing the Latino National Survey, Fraga et al. (2006b) find that linked fate is highest among foreignborn and Spanish dominant Latinos (after controlling for other factors). This suggests the weakening of ethnic attachments as a result of assimilation. We intend to advance this line of inquiry by examining the potential for immigration policy to motivate a sense of linked fate among Latinos. We anticipate that while immigration laws will increase Latino liked fate regardless of generational status, the impact will be more prominent among foreign-born Latinos due to the previous finding of higher linked fate among that segment of the Latino population, as well as the prominence of ethnic pride within the immigration movement (De Casanova 2012). 


\section{DATA AND METHODS}

To test our expectations, we rely on the 2012 Collaborative Multiracial Post-Election Survey ("CMPS II"), which is comprised 2,616 registered voters who self-identified as Black $(n=804)$, Latino $(n=934)$, or White $(n=878)$. For our analysis we restrict the sample to only Latino populations and merge these data with contextual state-level immigration information from the National Conference of State Legislatures. The GfK Group ("GfK"; formerly Knowledge Networks) conducted the survey between November 16 and 26, 2012 in both English and Spanish. The survey asked about voting and attitudes on social and economic issues prominent in the 2012 Election. The median completion time of the survey was $20 \mathrm{~min}$, and the completion rate was $56.3 \%$. Respondents were considered qualified if they did not refuse more than four of the first seven questions in the survey. Those who refused four or more of the first seven questions were terminated from the survey. The qualification rate was $99.8 \%$.

The 2012 CMPS used probability-based web panels designed to be representative of the United States. To reduce the effects of any non-response and non-coverage bias in the overall panel membership a post-stratification adjustment was applied based on demographic distributions from the most recent CPS (Current Population Survey) data. An additional Spanish-language adjustment was used based on the 2010 Pew Hispanic Center Survey (the most recent available published Latino data at the time). Language usage adjustments allow for the correct proportion of Spanish-speaking to English-speaking Hispanic and non-Hispanic panel members within Census regions. All reported results use probability weights that employ these post-interview adjustments.

The survey included 37 items dealing with sociopolitical attitudes, mobilization political activity, advertising exposure, and neighborhood context as well as questions on linked fate which we explore in this analysis. The survey also asked 15 items that capture demographic information, including age, ancestry, birthplace, education, income, group attachments, marital status, number in the household, religiosity, gender, sexual orientation, internet usage, and residential context. In addition, the survey data also include latitude and longitude values for each respondent, which allows us to merge state-level-immigration data to the survey in order to test hypotheses about the relationship between immigration laws and linked fate among the Latino electorate. 
The state-level immigration data come from the National Conference of State Legislatures from 2005 to 2012 (Ybarra, Sanchez, and Sanchez 2016). Ybarra, Sanchez, and Sanchez tediously coded each state law as beneficial if the law provided benefits or resources to immigrants and punitive if the law restricted benefits or was written to make life harder for immigrants. This merged dataset is unique in that they provide measures of beneficial laws and anti-immigrant legislation, linked fate, and a vector of control variables, which we utilized in our analysis. This is therefore an ideal dataset for our research question.

The primary outcome variable of interest is linked fate using two questions within the CMPS II dataset. The linked fate questions included in the CMPS II survey are very close in wording to the item included in the published work (Dawson 1994; Masuoka 2006; Sanchez and Masuoka 2010; Simien 2005; Tate 1991). The first question asks respondents if they have linked fate followed by a question that asks respondents to rate their linked fate. The specific survey questions we utilize are "Do you think what happens generally to [Hispanics] in this country will have something to do with what happens in your life?" Response categories - "Yes or No" The question is followed by, "Will it affect you a lot, some, or not very much?" Response categories - "Not at all, A little, Some, A lot." The coding of our dependent variable collapses both linked fate questions and is coded as $1=$ No and Not at all, $2=\mathrm{A}$ little, $3=$ Some, $4=\mathrm{A}$ lot. Approximately $59.71 \%$ of respondents answered "No/Not at all"; $7.92 \%$ answered "A little": $22.31 \%$ answered "Some"; and 10.04\% answered "A lot." 3 This distribution indicates sufficient variance and representation of each of the four response categories to allow reasonable estimations and tests of the hypotheses offered above.

Numerous studies have found the linked fate measure to produce reliable and valid results (Dawson 1994; Masuoka 2006; Sanchez and Masuoka 2010; Simien 2005). Linked fate, measured by Dawson (1994), has been especially well studied in relation to Latino group identity (Sanchez and Masuoka 2010). Linked fate has also been found to be associated with a variety of research focusing on language and nativity (Bernal et al. 1990; Ricourt and Danta 2003; Padilla 1985). Given that our study is examining differences within the population of U.S. Hispanics and having addressed the major methodological recommendations of scholars, we feel confident that our linked fate variable is a viable measure to test our hypotheses.

Our main explanatory variables are the total number of immigrant laws that were passed from 2005 to 2012 in each state. These data are merged 
with the CMPS II data using the geo-coded FIPS state indicators. Because laws can be beneficial and punitive toward immigrants, we use both types of laws in our study. Therefore, our measure differentiates between laws that are punitive and those that are beneficial toward immigrants, which is a key contribution to the literature. Figure 1, provides the trend of antiimmigrant laws and beneficial laws (and the sum of both laws) from 2005 to 2012. In general, laws that benefit immigrants outnumber punitive laws for all years except in the years 2009 and 2010. Interestingly enough, this trend comes at the end of the great recession as both unauthorized immigration began to decline and the Arizona's S.B. 1070 (2010) was passed, arguably the nation's broadest and strictest anti-immigrant law.

Maps 1 and 2 visually display the sum of anti-immigrant and beneficial laws for all states in the United States from 2005 to 2012 ( for the entire list see Appendix Table Al). In general, we find a great deal of anti-immigrant activity in two geographic clusters: the southwest region (AZ, CO, and UT) and the southeast region (AL, GA, and VA). Conversely, states such as CA, IL, WA, VA, and UT are enacting laws that benefit immigrants much more frequently.

Additional explanatory variables we include in our analysis are selfreported skin color, and experiences with racial/ethnic discrimination, two important factors relevant to group identity according to Dawson's theory of linked fate (Dawson 1994). We utilize the following question to measure skin color: "We are interested in how you would describe your appearance. How would you describe your skin color with 1 being very light and 5 being very dark or some number in between?" The categories of the variable are very light, light, medium, dark, and very dark. We approach the concept of skin color in line with scholars interested modeling skin color (Gravlee et al. 2005; Klonoff and Landrine 2000) who use self-reported skin color as opposed to research that measures skin color with reflectometers.

Our measure of discrimination experience utilizes the following survey question: "Have you personally experienced discrimination in the last year?" The response categories for this measure are $0=$ No and $l=$ Yes. This measure is specific to racial/ethnic discrimination, making it ideal for our purposes here. This measure is also very similar to the extant work focused on linked fate (Dawson 1994; Masuoka 2006; Sanchez and Masuoka 2010; Simien 2005; Tate 1991). Summary statistics for all variables used in this analysis are listed in the Appendix, Table A2.

Finally, we control for a handful of measures that have been found to be correlated with Latino linked fate in previous research. The inclusion of 


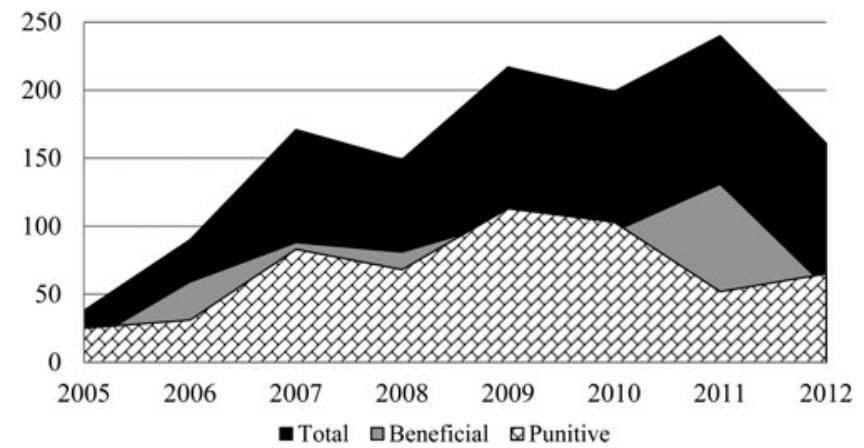

Figure 1. Immigration Laws from 2005 to 2012 (Ybarra, Sanchez, and Sanchez 2016).

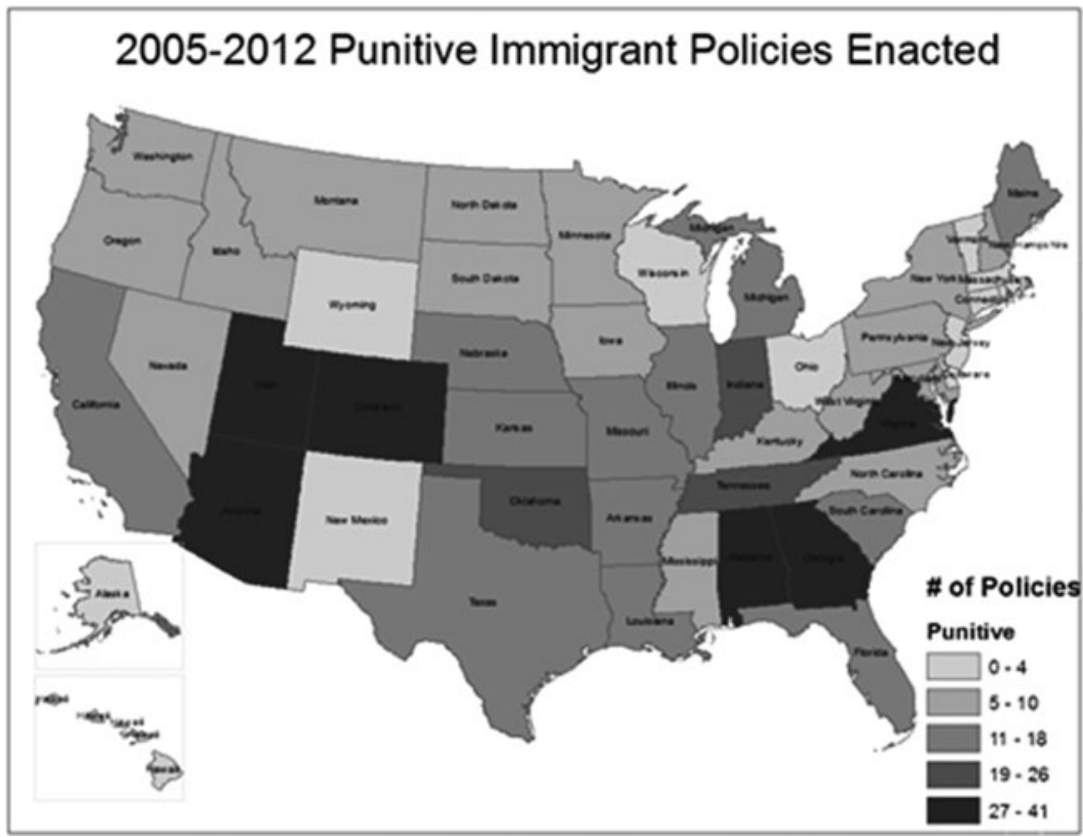

MaP 1. Punitive Immigrant Policies Enacted By State (Ybarra, Sanchez, and Sanchez 2016).

these factors is intended to provide clarity as to whether or not the relationship of interest in our analysis holds when other factors known to influence Latino linked fate are accounted for in the model. Among the demographic variables we include income, educational attainment, age, 


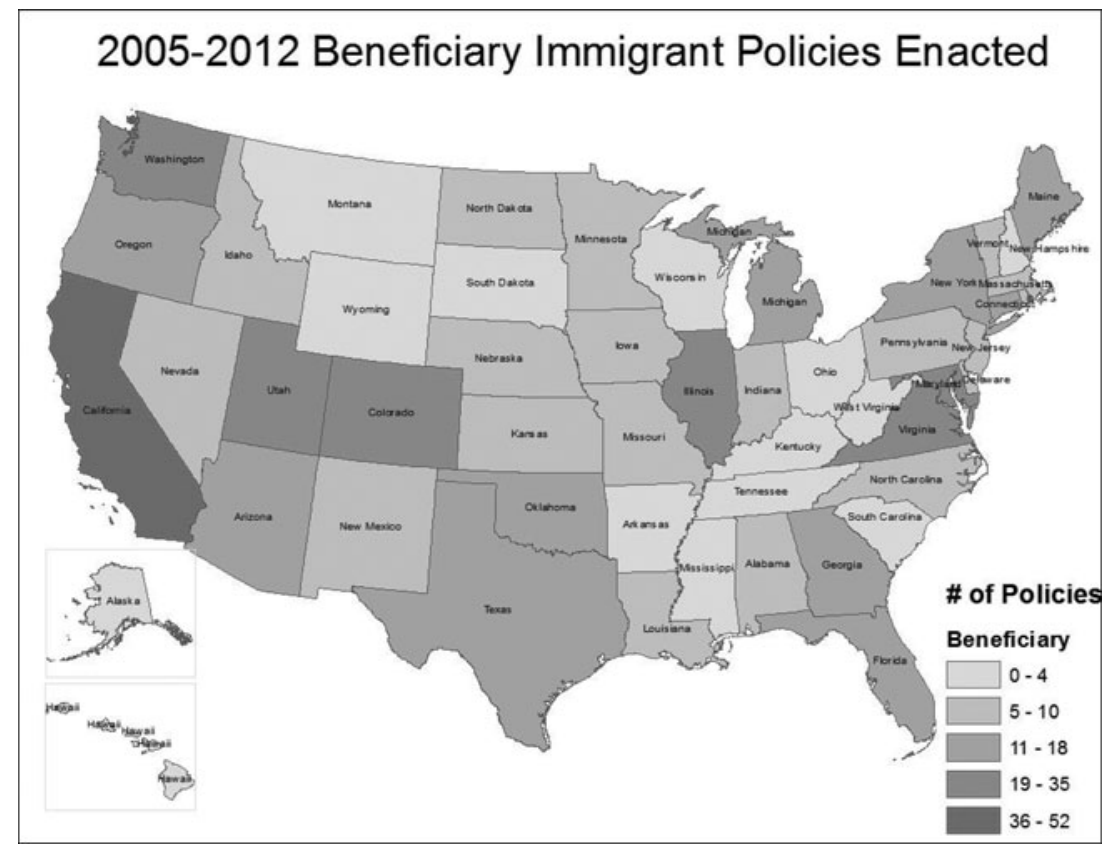

MAP 2. Beneficial Immigrant Policies Enacted By State (Ybarra, Sanchez, and Sanchez 2016).

and gender. The impact of socioeconomic status on linked fate is well established in the literature (Alba and Nee 2003; Dawson 1994; Sanchez and Masuoka 2010; Simien 2005). To assess income we have included a continuous measurement of household income: $1=<\$ 5,000,2=\$ 5,000-\$ 7,499,3=$ $\$ 7,500-\$ 9,999, \quad 4=\$ 10,000-\$ 12,999, \quad 5=\$ 12,500-\$ 14,999, \quad 6=\$ 15,000$ $\$ 19,999,7=\$ 20,000-\$ 24,999,8=\$ 25,000-\$ 29,000,9=\$ 30,000-\$ 34,999$, $10=\$ 35,000-\$ 39,999,11=\$ 40,000-\$ 49,000,12=\$ 50,000-\$ 59,000,13=$ $\$ 60,000-\$ 74,999, \quad 14=\$ 75,000-\$ 84,999, \quad 15=\$ 85,000-\$ 99,000, \quad 16=$ $\$ 100,000-\$ 124,999,17=\$ 125,000-\$ 149,999,18=\$ 150,000-\$ 174,999$, $19=\$ 175,000>$. To assess education we include a continuous measurement of highest education attained that ranges from $1=$ no formal education to $14=$ professional or doctoral degree. We also include a variable to control for whether the respondent was contacted by a public official $(0=\mathrm{no}, \mathrm{l}=$ yes). This measure of mobilization is intended to account for the prospect of outreach from candidates or parties that may have utilized immigration oriented messages in their ads and GOTV efforts (Barreto and Collingwood 2015). 
Finally, we control for several Latino-specific factors, which include Mexican origin, nativity and Spanish language. Research has documented that more acculturated Latinos, again often measured by language and nativity, report higher levels linked fate (Bernal et al. 1990; Ricourt and Danta 2003; Padilla 1985; Sanchez and Masuoka 2010).

Our analytic approach is focused on the effect immigrant legislation (punitive or beneficial) has on linked fate among Latinos. We code linked fate as a nominal outcome, in which we compare having "No/Not at All" linked fate versus "A little," "Some," and "A lot." We then run multinomial logistic regression on a full sample of Latinos and then isolate foreign-born Latinos and U.S.-born Latinos in separate models to examine the role nativity plays in the relationship between immigrant laws and linked fate. In estimating our models, we cluster on States to overcome the autocorrelation assumption, in that we have respondents nested within States, and all statistical analysis was conducted using Stata 12 software (StataCorp. 2011. Stata Statistical Software: Release 12. College Station, TX: StataCorp LP.).

\section{RESULTS}

We begin with a discussion of the distributions from our sample (which are provided in Appendix Table A2). After dropping missing data from non-response to items in our model $(n=204)$, we have a total sample of 730 Latino respondents. A large segment of our sample indicated that they had a little linked fate $(\mu=1.827)$. The mean age in our sample is 49 , just under half the sample is female (48\%), and the majority of our sample has at least a high school education and above (88\%). Moreover, about $23 \%$ of our sample completed the survey in Spanish, and over $31 \%$ of the sample indicated that they were foreign born. Regarding immigration laws, the distribution for punitive laws ranges from 1 (minimum) to 41 (maximum), with a mean of 15 laws $(\mathrm{SD}=8)$. Laws that benefit immigrants range from 1 (minimum) to 52 (maximum), with a mean of 27 laws $(\mathrm{SD}=18)$.

The results of the full multinomial logistic regressions used to test our hypotheses are reported in Table 1 (this analysis is among all Latinos). For the purpose of interpreting the multinomial logistic regression results, it should be noted that the comparison response category is "No/Not at all." The results show that both laws that are beneficial and laws that are punitive are statistically correlated with linked fate among Latinos. More 
Table 1. Full multinomial logit regression coefficient results among all Latinos, dependent variable $=$ linked fate, comparison response category $=$ "No/Not at all linked fate", $N=730$

\begin{tabular}{|c|c|c|c|c|c|c|}
\hline \multirow[b]{2}{*}{$\begin{array}{l}\text { Variable } \\
\text { description }\end{array}$} & \multicolumn{3}{|c|}{ Punitive laws } & \multicolumn{3}{|c|}{ Beneficial laws } \\
\hline & $\begin{array}{l}\text { Little | } \\
\text { No/Not } \\
\text { at all } \\
\beta\end{array}$ & $\begin{array}{l}\text { Some | } \\
\text { No/Not } \\
\text { at all } \\
\beta\end{array}$ & $\begin{array}{l}\text { A lot | } \\
\text { No/Not } \\
\text { at all } \\
\beta\end{array}$ & $\begin{array}{l}\text { Little | } \\
\text { No/Not } \\
\text { at all } \\
\beta\end{array}$ & $\begin{array}{l}\text { Some | } \\
\text { No/Not } \\
\text { at all } \\
\beta\end{array}$ & $\begin{array}{l}\text { A lot | } \\
\text { No/Not } \\
\text { at all } \\
\beta\end{array}$ \\
\hline Punitive laws & .012 & -.014 & $.039 \%$ & & & \\
\hline Beneficial laws & & & & $.018^{* * *}$ & -.004 & -.005 \\
\hline Skin color ${ }^{\mathrm{a}}$ & .195 & .008 & -.515 & .197 & .016 & -.511 \\
\hline Discrimination & -.043 & 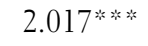 & 2.464 皮的 & -.106 & 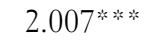 & 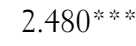 \\
\hline Age & -.006 & .004 & $-.025^{*}$ & -.005 & .004 & $-.026 *$ \\
\hline Education $^{\mathrm{b}}$ & .086 & .014 & .138 & .089 & .012 & .122 \\
\hline $\begin{array}{l}\text { Household } \\
\text { income }\end{array}$ & .047 & $-.100^{*}$ & $-.086^{*}$ & .041 & $-.098 *$ & -.076 \\
\hline Female & $.793 \%$ & -.103 & .387 & $.794^{* * * *}$ & -.097 & .397 \\
\hline Foreign born & .776 & -.119 & .148 & .715 & -.111 & .050 \\
\hline Spanish & -.279 & .938 & .860 & -.331 & .943 & .957 \\
\hline Mexican origin & .516 & .324 & .165 & .235 & .334 & .241 \\
\hline $\begin{array}{l}\text { Contacted by } \\
\text { public official }\end{array}$ & .131 & .177 & -.166 & .156 & .156 & -.097 \\
\hline Adjusted $R^{2}$ & .127 & & & .125 & & \\
\hline
\end{tabular}

Notes: ${ }^{* * * *} p<.01,{ }^{* * *} p<.05,{ }^{*} p<.1, \beta$ is a logit coefficient.

${ }^{\mathrm{a}}$ Skin color: $1=$ Very light, $2=$ Light, $3=$ Medium, $4=$ Dark, $5=$ Very dark.

${ }^{\mathrm{b}}$ Education: $1=$ No formal education; $2=1$ st, 2 nd, 3 rd, or 4 th grade; $3=5$ th or 6 th grade; $4=7$ th or 8th grade; $5=9$ th grade; $6=10$ th grade; $7=11$ th grade; $8=12$ th grade no diploma; $9=$ High school graduate-high school diploma; 10 = Some college, no degree; 11 = Associate degree; 12 = Bachelor's degree; $13=$ Master's degree; $14=$ Professional or doctorate.

${ }^{\mathrm{c}}$ Household income: $1=<\$ 5,000,2=\$ 5,000-\$ 7,499,3=\$ 7,500-\$ 9,999,4=\$ 10,000-\$ 12,999,5=$ $\$ 12,500-\$ 14,999,6=\$ 15,000-\$ 19,999,7=\$ 20,000-\$ 24,999,8=\$ 25,000-\$ 29,000,9=\$ 30,000$ $\$ 34,999,10=\$ 35,000-\$ 39,999,11=\$ 40,000-\$ 49,000,12=\$ 50,000-\$ 59,000,13=\$ 60,000$ $\$ 74,999,14=\$ 75,000-\$ 84,999,15=\$ 85,000-\$ 99,000,16=\$ 100,000-\$ 124,999,17=$ $\$ 125,000-\$ 149,999,18=\$ 150,000-\$ 174,999,19=\$ 175,000>$.

specifically, for each additional punitive law enacted, the probability of reporting "A lot" of linked fate increases compared with reporting "No/ Not at all" linked fate, holding all other variables constant at the .05 level of significance. This is consistent with our theory and suggests that the immigration climate is increasing a sense of solidarity among Latinos. Somewhat surprisingly, laws that are beneficial to immigrants are also having an effect on linked fate among Latinos. Although beneficial laws do not have a significant relationship with the highest category of 
the linked fate measure ("A lot"), we do find that these laws increase the probability of reporting "A little" linked fate compared with reporting "No/ Not at all" linked fate, holding all other variables constant, which is statistically significant at the .05 level. In short, we find that immigration laws, regardless of whether they are negative or punitive, are moving Latinos who have had no sense of linked fate with other Latinos to higher values on that measure. Increased exposure to punitive or negative laws is actually motivating Latinos who had no sense of linked fate to the highest level of the variable.

The results of the foreign born multinomial logistic regressions are reported in Appendix Table A3. For the purpose of interpreting the results, it should be noted that the comparison response category is also "No/Not at all." Results show that both laws that are beneficial and laws that are punitive are statistically correlated with linked fate among foreignborn Latinos. More specifically, for each additional punitive law enacted, the probability of reporting "A lot" of linked fate increases compared with reporting "No/Not at all," holding all other variables constant at the .01 level of significance. This is consistent with our theory and suggests that foreign-born Latinos are more sensitive to immigration laws. We also find that immigrant laws that are beneficial to immigrants are also having an effect on linked fate among foreign-born Latinos. Laws that benefit immigrants decrease the probability of reporting "Some" and increase the likelihood of reporting "A lot" of linked fate compared with reporting "No/Not at all" linked fate, holding all other variables constant $(p<.01$ and $p<.05$, respectively).

The results of the U.S.-born multinomial logistic regressions are reported in Appendix Table A4, and the comparison response category is also "No/Not at all." Results show that both laws that are beneficial and laws that are punitive are statistically correlated with linked fate among U.S.-born Latinos. More specifically, for each additional punitive law enacted, the probability of reporting "A lot" of linked fate increases compared with reporting "No/Not at all" linked fate, holding all other variables constant, which is significant at the .05 level. Interestingly, we also find that immigrant laws that are beneficial to immigrants are also having an effect on linked fate among U.S.-born Latinos. Laws that benefit immigrants increase the probability of reporting "A little" linked fate compared with reporting "No/Not at all" linked fate, holding all other variables constant $(p<.01)$. These are interesting and important results, as they suggest that the influence of the heightened immigration policy climate across the American states on Latino identity is not limited to those directly impacted 
by the legislation, Latino immigrants. Rather, this recent rise in state-level immigration laws is having a more wide-spread impact on Latino linked fate, revealing a more broad sense of collective identity.

In addition to our measures of immigration laws, we briefly discuss the performance of the control variables in our full sample as well. The sociodemographic factors are very meaningful, as essentially all of these controls have an impact on Latino liked fate. In line with the extant literature on the relationship between discrimination and linked fate, discrimination is positively correlated with linked fate among Latinos (Dawson 1994; Sanchez and Masuoka 2010). We also find a relationship between income and linked fate, as income is negatively correlated with linked fate among Latinos.

Furthermore, age is negatively correlated with responding "A lot" of linked fate compared with "No/Not at all." Therefore, older Latinos are less likely to report "A lot of linked fate" relative to "No/Not at all" compared with respondents who are younger. Gender also plays role, as we find women compared with men report "A little" linked fate compared with "No/Not at all". Finally, language of interview does not factor in linked fate acquisition. We also find no differences for Latinos who are foreign-born compared with U.S.-born when it comes to linked fate in our full sample; however, as shown in our analysis, subdividing the sample by nativity has provided us with a wealth of information. For example, among U.S.-born Latinos, we do find that respondents of Mexican origin are more likely to report "A little" linked fate compared with "No/Not at all." In general, the fact that our control variables are in line with the extant literature lends some confidence to the results.

\section{CONCLUSIONS AND DISCUSSION}

As our nation's policy makers continue struggling to pass comprehensive immigration reform, state and local governments have taken it upon themselves to act on immigration policy. This is reflected in the record number of laws that have been proposed and passed across the American states over the last decade of heightened policy action at the state level. Although the President has utilized his executive powers to address several aspects of immigration policy, Congress has failed to pass major legislation in this domain at the time of submission. This will undoubtedly lead to more state-level laws as well as a continued sociopolitical climate that is 
hostile toward immigrants, particularly Latino immigrants. The Trump presidential campaign has reinforced this divisive climate, with the president elect launching his campaign with inflammatory statements regarding Mexican immigrants and proposing to build a wall along the U.S.-Mexico border that Mexico would pay for. Results from our analysis suggest that these policies have a direct impact on Latino group identity.

Regardless of whether these laws are punitive or beneficial to immigrants, they are increasing levels of linked fate among the Latino population. It is important to note that our findings hold even after we control for additional explanatory variables connected to linked fate in the literature, and, in line with previous studies, our analysis yields that discrimination is positively correlated with linked fate among Latinos. This is an important finding as it suggests that public policies can have a direct impact on the panethnic identity of communities. This provides a new perspective to the work attempting to identify contributing factors to group identity among racial and ethnic communities. The centrality of linked fate to the discussion of minority political behavior makes this analysis relevant to a wider range of research than just identity politics. For example, the relationship between immigration laws and Latino group identity may help explain a shift in policy preferences among the Latino population over time, as well as a clear increase in the salience of immigration policy to the voting behavior of Latinos. With Latinos now composing the largest single minority in the United States, it is crucial to understand the complexities of Latino political behavior.

Lastly, while our analysis focuses on laws as a proxy for immigrant sentiment, future research should examine other measures of immigrant sentiment such as risk of deportation (Vargas 2015) or the impacts of the late $287(\mathrm{~g})$ program, or immigration raids on group identity. This might help us acquire more leverage on this relationship by providing additional mechanisms for immigration policy to dive Latino group identity. Finally, given that our analysis is constrained to the 2012 Election, a year in which researchers have found immigration themed mobilization efforts were targeted toward Latinos (Barreto and Collingwood 2015; Collingwood, Barreto, and García-Rios 2014), researchers should explore whether a similar relationship exists in other election cycles where immigration focused mobilization may have been more varied by state. That said, with immigration playing a dominant role in the 2016 primary and general election campaigns, it may be some time before we see a major shift in the political climate surrounding immigration. 


\section{Acknowledgments}

The project described is supported, in part, by a NICHD training grant to the University of Wisconsin-Madison (T32HD049302) and the Robert Wood Johnson Foundation Center for Health Policy at the University of New Mexico. The content is solely the responsibility of the authors and does not necessarily represent the official views of the Eunice Kennedy Shriver National Institute of Child Health and Human Development, the National Institutes of Health, or the Robert Wood Johnson Foundation. The authors would also like to thank $\operatorname{Dr}(\mathrm{s})$. Vickie D. Ybarra and Lisa M. Sanchez.

\section{NOTES}

1. HB 56, The Beason-Hammon Alabama Taxpayer and Citizen Protection Act http://www.legislature. state.al.us/

2. http://www.latinodecisions.com/files/1214/2707/3700/UNM_RWJF_Center_Toplines_Posted.pdf

3. The unweighted distribution of linked fate in the Latino National Survey is as follows: Nothing $(8.01 \%)$, Little (12.98\%), Some (25.03\%), Lot (49.19\%), DK/NA $(7.78 \%)$.

\section{REFERENCES}

Alba, Richard D., and Victor Nee. 2003. "Assimilation Theory, Old and New." In Remaking the American Mainstream Assimilation and Contemporary Immigration. Cambridge, MA: Harvard University Press, 28-35.

Barreto, Matt, and Loren Collingwood. 2015. "Group-Based Appeals and the Latino Vote in 2012: How Immigration Became a Mobilizing Issue." Electoral Studies 40, 490-99.

Barreto, Matt, Masuoka Natalie, and Gabriel Sanchez. 2008. "Discrimination and Group Consciousness Among Muslim Americans." Paper Presented at the Annual Meeting of the Western Political Science Association, Manchester Hyatt, San Diego, California.

Barreto, Matt, Sylvia Manzano, Ricardo Ramírez, and Kathy Rim. 2009. "Immigrant Social Movement Participation: Understanding Involvement in the 2006 Immigration Protest Rallies." Urban Affairs Review 44 (5): 736-64.

Beltran, Cristina. 2010. The Trouble with Unity: Latino Politics and the Creation of Identity. Oxford: Oxford University Press, 4-33.

Bernal, Martha E., George P. Knight, Camille A. Garza, Katheryn A. Ocampo, and Marya K. Cota. 1990. "The Development of Ethnic Identity in Mexican-American Children." Hispanic Journal of Behavioral Sciences 12 (1): 3-24.

Branscombe, Nyla R., Michael T. Schmitt, and Richard D. Harvey. 1999. "Perceiving Pervasive Discrimination among African Americans: Implications for Group Identification and Well-being." Journal of Personality and Social Psychology 77 (1): $135-49$.

Brettell, Caroline B., and Faith G. Nibbs. 2011. "Immigrant Suburban Settlement and the 'Threat' to Middle Class Status and Identity: The Case of Farmers Branch, Texas." International Migration 49 (1): 1-30. doi:10.1111/j.1468-2435.2010.00611.x

Bump, M. 2005. "Temporary Picking to Permanent Plucking: Hispanic Newcomers, Integration, and Change in the Shenandoah Valley." In Beyond the Gateway: 
Immigrants in a Changing America, eds. E. Gozdziak and S. F. Martin. Lanham: Lexington Books, 137-75.

Central Alabama Fair Housing Center, Et Al. V. Julie Magee, Et Al. 2011. 2:11-cv-00982-MHT-CSC. https://www.splcenter.org/sites/default/files/d6_legacy_files/ downloads/case/70-0_CAFHC_Emergency_MotionEnforce.pdf

Chavez, Jorge M., and Doris M. Provine. 2009. "Race and the Response of State Legislatures to Unauthorized Immigrants." The Annals of the American Academy of Political and Social Science 623 (1): 78-92. doi: 10.1177/0002716208331014.

Chavez, Leo. 2008. The Latino Threat: Constructing Immigrants, Citizens, and the Nation. Stanford, CA: Stanford University Press.

Collingwood, Loren, Matt Barreto, and Sergio García-Rios. 2014. "Revisiting Latino Voting: Cross-Racial Mobilization in the 2012 Election." Political Research Quarterly 67: 4 .

Conover, Pamela Johnston. 1984. "The Influence of Group Identification on Political Perception and Evaluation." The Journal of Politics 46 (3): 760-85.

Dawson, Michael C. 1994. Behind the Mule: Race and Class in African-American Politics. Princeton, NJ: Princeton University Press.

De Casanova, Erynn Masi. 2012. "Organizing Identities: Immigrant New Yorkers Negotiating Latinidad." Sociological Forum 27 (2): 419-40.

Félix, Adrián. 2008. "New Americans or Diasporic Nationalists?: Mexican Migrant Responses to Naturalization and Implications for Political Participation." American Quarterly 60 (3): 601-24.

Fraga, Luis R., John A. Garcia, Rodney E. Hero, Michael Jones-Correa, Valerie Martinez-Ebers, and Gary M. Segura. 2006a. "Su Casa Es Nuestra Casa: Latino Politics Research and the Development of American Political Science." American Political Science Review 100 (4): 515-21.

Fraga, Luis R., John A. Garcia, Rodney Hero, Michael Jones-Correa, Valerie Martinez-Ebers, and Gary M. Segura. 2006b. Latino National Survey (LNS). ICPSR20862-v6. Ann Arbor, MI: Inter-university Consortium for Political and Social Research [distributor], 2013-06- 05. http://doi.org/10.3886/ICPSR20862.v6

Galindo, René. 2011. "The Nativistic Legacy of the Americanization Era in the Education of Mexican Immigrant Students." Educational Studies 47 (4): 323-46.

Galindo, René, and Jami Vigil. 2006. "Are Anti-Immigrant Statements Racist or Nativist? What Difference Does It Make?" Latino Studies 4 (4): 419-47.

Garcia, John. 2003. "Latino Politics in the United States." In Dictionary of Race and Ethnic Relations, ed. Ellis Cashmore. New York: Routledge, 255-76.

Gravlee, Clarence C., William W. Dressler, and H. Russell Bernard. 2005. "Skin Color, Social Classification, and Blood Pressure in Southeastern Puerto Rico." American Journal of Public Health 95 (12): 2191-97.

Gulasekaram, Pratheepan, and S. Karthick Ramakrishnan. 2013. "Immigration Federalism: A Reappraisal." New York University Law Review NYU Law Review 88: 2074-145.

Gulasekaram, Pratheepan, and S. Karthick Ramakrishnan. 2015. The New Immigration Federalism. New York: Cambridge University Press.

Hackel, Leor M., Christine E. Looser, and Jay J. Van Bavel. 2014. "Group Membership Alters the Threshold for Mind Perception: The Role of Social Identity, Collective Identification, and Intergroup Threat." Journal of Experimental Social Psychology 52: $15-23$.

Hopkins, Daniel. 2010. "Politicized Places: Explaining Where and When Immigrants Provoke Local Opposition.” American Political Science Review 104 (1): 40-60. 
Huddy, Leonie. 2001. "From Social to Political Identity: A Critical Examination of Social Identity Theory." Political Psychology 22 (1): 127-56.

Johnson, Kevin R. 2012. "Immigration and Civil Rights: State and Local Efforts to Regulate Immigration. (Symposium: Civil Rights or Civil Wants?)." Georgia Law Review 46 (3): 609-38.

Klonoff, Elizabeth A. and Hope Landrine. 2000. "Is Skin Color a Marker for Racial Discrimination? Explaining the Skin Color-Hypertension Relationship." Journal of Behavioral Medicine 23 (4): 329-38.

Leighley, Jan E. 2001. Strength in Numbers?: The Political Mobilization of Racial and Ethnic Minorities. Princeton, NJ: Princeton University Press.

Lien, Pei, M. Margaret Conway and Janelle Wong. 2004. The Politics of Asian Americans: Diversity and Community. New York: Routledge.

Magaña, Lisa. 2013. "SB 1070 and Negative Social Constructions of Latino Immigrants in Arizona." Aztlán: A Journal of Chicano Studies 38 (2): 1151-61.

Marks, Mara, Stephen Nuno, and Gabriel R. Sanchez. 2009. "Look Back in Anger: Voter Opinions of Mexican Immigrants in the Aftermath of the 2006 Immigration Demonstrations." Urban Affairs Review 44 (5): 695-717.

Massey, Douglas S., and Magaly Sanchez R. 2010. Brokered Boundaries: Creating Immigrant Identity in Anti-Immigrant Times. New York: Russell Sage Foundation Press.

Masuoka, Natalie. 2006. "Together They Become One: Examining the Predictors of Panethnic Group Consciousness among Asian Americans and Latinos." Social Science Quarterly 87 (5): 993-1011.

Mcclain, Paula D., Jessica D. Johnson Carew, Eugene Walton, and Candis S. Watts. 2009. "Group Membership, Group Identity, and Group Consciousness: Measures of Racial Identity in American Politics?" Annual Review of Political Science 12: 471-85.

Miller, Arthur H., Patricia Gurin, Gerald Gurin, and Oksana, Malanchuk. 1981. "Group Consciousness and Political Participation." American Journal of Political Science 25 (3): 494-511.

Monogan, James III. 2013. "The Politics of Immigrant Policy in the 50 U.S. States. 20052011." Journal of Public Policy 33 (1): 35-64.

Olson, Mancur. 1965. The Logic of Collective Action: Public Goods and the Theory of Groups. Cambridge, MA: Harvard University Press.

Omi, Michael, and Howard Winant. 2014. Racial Formation in the United States. Routledge, NY: Taylor \& Francis.

Padilla, Felix. 1985. Latino Ethnic Consciousness: The Case of Mexican Americans and Puerto Ricans in Chicago. 1st ed. Indiana: University of Notre Dame Press.

Perreira, Krista M. 2011. "Mexican Families in North Carolina: The Socio-historical Contexts of Exit and Settlement." Southeastern Geographer 51 (2): 260-86.

Przeworski, Adam. 1985. Capitalism and Social Democracy. Cambridge: Cambridge University Press.

Ramirez, Ricardo. 2013. Mobilizing Opportunities: The Evolving Latino Electorate and the Future of American Politics. Charlottesville, VA: University of Virginia Press.

Ricourt, Milagros, and Ruby Danta. 2003. Hispanas De Queens: Latino Panethnicity in a New York City Neighborhood. Ithaca, NY: Cornell University Press.

Sanchez, G. R. 2006. "The Role of Group Consciousness in Latino Public Opinion." Political Research Quarterly 59 (3): 435-46.

Sanchez, G. R., and N. Masuoka. 2010. "Brown-Utility Heuristic? The Presence and Contributing Factors of Latino Linked Fate.” Hispanic Journal of Behavioral Sciences 32 (4): 519-31. 
Selden, David A., Julie A. Pace, and Heidi Nunn-Gilman. 2011. "Placing S.B. 1070 and Racial Profiling into Context, and What S.B. 1070 Reveals about the Legislative Process in Arizona." Arizona State Law Journal 43 (2): 523-61.

Simien, Evelyn. 2005. "Race, Gender, and Linked Fate." Journal of Black Studies 35 (5): 529-50.

Tajfel, Henri. 1981. Human Groups and Social Categories: Studies in Social Psychology. Cambridge [Cambridgeshire]: Cambridge University Press.

Tate, Katherine. 1991. "Black Political Participation in the 1984 and 1988 Presidential Elections." The American Political Science Review 85 (4): 1159-76.

Tate, Katherine. 1993. From Protest to Politics: The New Black Voters in American Elections. New York: Russell Sage Foundation.

Torres, Rebecca Maria, and Melissa Wicks-Asbun. 2013. "Undocumented Students' Narratives of Liminal Citizenship: High Aspirations, Exclusion, and "In-Between" Identities." The Professional Geographer 66 (2): 195-204.

Vargas, Edward D. 2015. "Immigration Enforcement and Mixed-Status Families: The Effects of Risk of Deportation on Medicaid Use." Children Youth Services Review In Press. http://www.sciencedirect.com/science/article/pii/S0190740915300177

Vélez, Veronica, Lindsay Perez Huber, Corina Benavides Lopez, Ariana De La Luz, and Daniel Solórzano. 2008. "Battling for Human Rights and Social Justice: A Latina/o Critical Race Media Analysis of Latina/o Student Youth Activism in the Wake of 2006 Anti-Immigrant Sentiment." Social Justice 7-27.

Verba, Sidney, and Norman H. Nie. 1972. Participation in America: Political Democracy and Social Equality. New York: Harper \& Row.

Wallace, Sophia J. 2014. "Papers Please: An Analysis of State Level Anti-Immigrant Legislation in the Wake of Arizona's SB 1070." Political Science Quarterly 129 (2): 261-91.

Winders, Jamie. 2011. "Representing the Immigrant: Social Movements, Political Discourse, and Immigration in the U.S. South." Southeastern Geographer 51 (4): 596-614.

Wiley, Shaun, Jessica Figueroa, and Taylor Lauricella. 2014. "When Does Dual Identity Predict Protest? The Moderating Roles of Anti-Immigrant Policies and Opinion-Based Group Identity." European Journal of Social Psychology 44: 209-15.

Ybarra, Vickie D., Lisa M. Sanchez, and Gabriel R. Sanchez. 2016. "Anti-Immigrant Anxieties in State Policy: The Great Recession and Punitive Immigration Policy in the American States, 2005-2012." State Politics and Policy Quarterly 16 (3): 313-39.

Zepeda-Millan, Chris. 2014. "Framing of Illegality: Explaining (non)Participation in New York's 2006 Immigrant Protests.” Political Research Quarterly 67 (4): 880-88. 


\section{APPENDIX}

Table Al. Sum of anti-immigrant and beneficial immigrant laws enacted 2005-2012 (Ybarra, Sanchez, and Sanchez 2016), by state (sorted high to low)

\begin{tabular}{|c|c|c|c|c|c|c|c|}
\hline \multirow{3}{*}{$\frac{\text { State }}{\text { GA }}$} & \multicolumn{3}{|c|}{ Punitive immigration laws } & \multicolumn{4}{|c|}{ Beneficial immigration laws } \\
\hline & \multirow{2}{*}{$\frac{\text { Number of laws }}{41}$} & \multicolumn{2}{|c|}{ Continued... } & \multirow{2}{*}{$\begin{array}{l}\text { State } \\
\mathrm{CA}\end{array}$} & \multirow{2}{*}{$\frac{\text { Number of laws }}{52}$} & \multicolumn{2}{|c|}{ Continued... } \\
\hline & & MD & 8 & & & $\mathrm{DE}$ & 7 \\
\hline UT & 40 & MT & 8 & IL & 35 & HI & 7 \\
\hline AZ & 38 & WV & 8 & UT & 28 & KS & 7 \\
\hline $\mathrm{CO}$ & 36 & $\mathrm{MN}$ & 7 & WA & 28 & MA & 7 \\
\hline VA & 36 & PA & 7 & VA & 26 & $\mathrm{NV}$ & 7 \\
\hline $\mathrm{AL}$ & 33 & $\mathrm{SD}$ & 7 & $\mathrm{CO}$ & 22 & ND & 7 \\
\hline $\mathrm{TN}$ & 26 & WA & 7 & MA & 21 & PA & 7 \\
\hline OK & 23 & IA & 6 & AZ & 18 & RI & 7 \\
\hline IN & 19 & $\mathrm{NH}$ & 6 & FL & 18 & NJ & 6 \\
\hline $\mathrm{SC}$ & 18 & $\mathrm{NY}$ & 6 & NY & 17 & ID & 5 \\
\hline FL & 17 & $\mathrm{NC}$ & 6 & TX & 17 & $\mathrm{NC}$ & 5 \\
\hline $\mathrm{CA}$ & 16 & KY & 5 & GA & 14 & $\mathrm{VT}$ & 5 \\
\hline MO & 16 & $\mathrm{NV}$ & 5 & MI & 13 & KY & 4 \\
\hline KS & 14 & ND & 5 & CT & 12 & $\mathrm{NH}$ & 4 \\
\hline $\mathrm{NE}$ & 14 & RI & 4 & ME & 11 & $\mathrm{OH}$ & 4 \\
\hline TX & 14 & CT & 3 & OK & 11 & SC & 4 \\
\hline AR & 13 & MA & 3 & OR & 11 & $\mathrm{TN}$ & 4 \\
\hline HI & 13 & $\mathrm{NJ}$ & 3 & LA & 10 & WV & 4 \\
\hline IL & 13 & NM & 3 & MO & 10 & $\mathrm{AK}$ & 3 \\
\hline MI & 13 & VT & 3 & $\mathrm{NE}$ & 10 & AR & 3 \\
\hline LA & 12 & WY & 3 & IA & 9 & MT & 3 \\
\hline $\mathrm{ME}$ & 12 & $\mathrm{AL}$ & 2 & IN & 8 & SD & 2 \\
\hline ID & 10 & DE & 2 & MN & 8 & WY & 2 \\
\hline MS & 10 & $\mathrm{OH}$ & 2 & NM & 8 & MS & 1 \\
\hline OR & 10 & WI & 1 & $\mathrm{AL}$ & 7 & WI & l \\
\hline
\end{tabular}


Table A2. Descriptive statistics for dependent, independent, and control variables $(n=730)$

\begin{tabular}{lrrrr}
\hline Variable descriptions & Mean & SD & Min & Max \\
\hline Linked fate $^{\mathrm{a}}$ & 1.827 & 1.092 & 1 & 4 \\
Punitive laws & 14.895 & 7.954 & 1 & 41 \\
Beneficial laws & 26.565 & 17.525 & 1 & 52 \\
Age & 48.645 & 14.938 & 18 & 88 \\
Less High School & .125 & .331 & 0 & 1 \\
Skin color & 2.397 & .773 & 1 & 5 \\
Discrimination $^{\mathrm{b}}$ & .211 & .408 & 0 & 1 \\
Education $^{\mathrm{c}}$ & 9.986 & 2.371 & 1 & 14 \\
Household income $^{\mathrm{d}}$ & 11.493 & 4.458 & 1 & 19 \\
Female $^{\text {Foreign born }}$ & .480 & .500 & 0 & 1 \\
Spanish $^{\mathrm{f}}$ & .313 & .464 & 0 & 1 \\
Mexican origin $^{\mathrm{g}}$ & .233 & .423 & 0 & 1 \\
Contacted by public official $^{\mathrm{h}}$ & .447 & .497 & 0 & 1 \\
\hline
\end{tabular}

Notes:

${ }^{a}$ Linked fate (four-choice outcome): 1 = "No/Not at all," 2 = "Little," 3 = "Some," 4 = "A lot."

${ }^{\mathrm{b}}$ Skin color: 1 =Very light, $2=$ Light, $3=$ Medium, $4=$ Dark, $5=$ Very dark.

${ }^{\mathrm{c}}$ Education: $1=$ No formal education; $2=1$ st, 2 nd, $3 \mathrm{rd}$, or 4 th grade; $3=5$ th or 6 th grade; $4=7$ th or 8th grade; $5=9$ th grade; $6=10$ th grade; $7=11$ th grade; $8=12$ th grade no diploma; $9=$ High school graduate - high school diploma; $10=$ Some college, no degree; $11=$ Associate degree; $12=$ Bachelor's degree; $13=$ Master's degree; $14=$ Professional or doctorate.

${ }^{\mathrm{d}}$ Household income: $1=<\$ 5,000,2=\$ 5,000-\$ 7,499,3=\$ 7,500-\$ 9,999,4=\$ 10,000-\$ 12,999,5=$ $\$ 12,500-\$ 14,999, \quad 6=\$ 15,000-\$ 19,999, \quad 7=\$ 20,000-\$ 24,999, \quad 8=\$ 25,000-\$ 29,000, \quad 9=\$ 30,000-$ $\$ 34,999,10=\$ 35,000-\$ 39,999,11=\$ 40,000-\$ 49,000,12=\$ 50,000-\$ 59,000,13=\$ 60,000-\$ 74,999$, $14=\$ 75,000-\$ 84,999,15=\$ 85,000-\$ 99,000,16=\$ 100,000-\$ 124,999,17=\$ 125,000-\$ 149,999,18=$ $\$ 150,000-\$ 174,999,19=\$ 175,000>$.

${ }^{\mathrm{e}}$ Foreign Born: $0=$ U.S. Born, $\mathrm{l}=$ Foreign born.

${ }^{\mathrm{f}}$ Spanish: Survey administered in $0=$ English, $\mathrm{l}=$ Spanish.

${ }^{g}$ Mexican origin: $0=$ Non-Mexican origin, $\mathrm{l}=$ Mexican origin.

${ }^{\mathrm{h}}$ Contacted by public official: $0=$ No, $\mathrm{l}=$ Yes. 
Table A3. Full multinomial logit regression coefficient results among foreign-born Latinos, dependent variable $=$ linked fate, comparison response category $=$ "No/Not at all linked fate", $N=253$

\begin{tabular}{|c|c|c|c|c|c|c|}
\hline \multirow[b]{2}{*}{ Variable description } & \multicolumn{3}{|l|}{ Punitive laws } & \multicolumn{3}{|l|}{ Beneficial laws } \\
\hline & $\begin{array}{l}\text { Little } \mid \text { No/Not at } \\
\text { all } \\
\beta\end{array}$ & $\begin{array}{l}\text { Some } \mid \text { No/Not } \\
\text { at all } \\
\beta\end{array}$ & $\begin{array}{l}\text { A lot } \mid \text { No/Not at } \\
\text { all } \\
\beta\end{array}$ & $\begin{array}{l}\text { Little } \mid \text { No/Not } \\
\text { at all } \\
\beta\end{array}$ & $\begin{array}{l}\text { Some } \mid \text { No/Not } \\
\text { at all } \\
\beta\end{array}$ & $\begin{array}{l}\text { A lot } \mid \text { No/Not at } \\
\text { all } \\
\beta\end{array}$ \\
\hline Punitive laws & -.046 & -.046 & 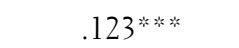 & & & \\
\hline Beneficial laws & & & & .001 & 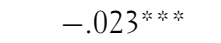 & $.044 \%$ \\
\hline Skin color ${ }^{\mathrm{a}}$ & .173 & .579 & -.376 & .373 & .654 & -.622 \\
\hline Discrimination & -1.841 & 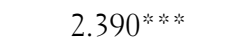 & $1.565^{* * ; *}$ & -1.840 & 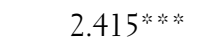 & $1.484^{* * 2 * x^{*}}$ \\
\hline Age & .017 & .010 & 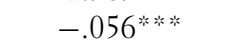 & .012 & .012 & $-.053^{\text {皮棌 }}$ \\
\hline Education ${ }^{\mathrm{b}}$ & -.128 & -.119 & .126 & -.108 & -.136 & .136 \\
\hline Household income ${ }^{c}$ & 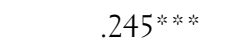 & -.002 & -.108 & $.247^{* * *}$ & .018 & -.133 \\
\hline Female & $1.781^{*}$ & -.714 & -.253 & $1.749^{*}$ & -.710 & -.077 \\
\hline Spanish & .224 & 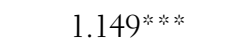 & .161 & .242 & 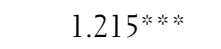 & -.013 \\
\hline Mexican origin & -.010 & -.287 & .955 & -.065 & -.029 & .010 \\
\hline $\begin{array}{l}\text { Contacted by public } \\
\text { official }\end{array}$ & $-1.667^{* *}$ & .710 & .438 & -1.508 & .710 & .413 \\
\hline Adjusted $R^{2}$ & .214 & & & .216 & & \\
\hline
\end{tabular}

Notes: ***** $p<.01, * * p<.05, * p<.1, \beta$ is a logit coefficient.

${ }^{\text {a }}$ Skin color: $1=$ Very light, $2=$ Light, $3=$ Medium, $4=$ Dark, $5=$ Very dark.

${ }^{\mathrm{b}}$ Education: $1=$ No formal education; $2=1$ st, 2 nd, 3rd, or 4th grade; $3=5$ th or 6 th grade; $4=7$ th or 8 th grade; $5=9$ th grade; $6=10$ th grade; $7=11$ th grade; $8=$ 12th grade no diploma; 9 = High school graduate-high school diploma; $10=$ Some college, no degree; 11 = Associate degree; $12=$ Bachelor's degree; $13=$ Master's degree; $14=$ Professional or doctorate.

${ }^{\mathrm{c}}$ Household income: $1=<\$ 5,000,2=\$ 5,000-\$ 7,499,3=\$ 7,500-\$ 9,999,4=\$ 10,000-\$ 12,999,5=\$ 12,500-\$ 14,999,6=\$ 15,000-\$ 19,999,7=\$ 20,000-$ $\$ 24,999,8=\$ 25,000-\$ 29,000,9=\$ 30,000-\$ 34,999,10=\$ 35,000-\$ 39,999,11=\$ 40,000-\$ 49,000,12=\$ 50,000-\$ 59,000,13=\$ 60,000-\$ 74,999,14=$ $\$ 75,000-\$ 84,999,15=\$ 85,000-\$ 99,000,16=\$ 100,000-\$ 124,999,17=\$ 125,000-\$ 149,999,18=\$ 150,000-\$ 174,999,19=\$ 175,000>$. 
Table A4. Full multinomial logit regression coefficient results among U.S.-born Latinos, dependent variable $=$ linked fate, comparison response category $=$ "No/Not at all linked fate", $N=507$

\begin{tabular}{|c|c|c|c|c|c|c|}
\hline \multirow[b]{2}{*}{ Variable description } & \multicolumn{3}{|l|}{ Punitive laws } & \multicolumn{3}{|l|}{ Beneficial laws } \\
\hline & $\begin{array}{l}\text { Little } \mid \text { No/Not } \\
\text { at all } \\
\beta\end{array}$ & $\begin{array}{l}\text { Some } \mid \mathrm{No} / \mathrm{Not} \\
\text { at all } \\
\beta\end{array}$ & $\begin{array}{l}\text { A lot } \mid \text { No/Not at } \\
\text { all } \\
\beta\end{array}$ & $\begin{array}{l}\text { Little } \mid \text { No/Not at } \\
\text { all } \\
\text { B }\end{array}$ & $\begin{array}{l}\text { Some } \mid \text { No/Not } \\
\text { at all } \\
\beta\end{array}$ & $\begin{array}{l}\text { A lot } \mid \text { No/Not at } \\
\text { all } \\
\beta\end{array}$ \\
\hline Punitive laws & .032 & .004 & $.038^{* * *}$ & & & \\
\hline Beneficial laws & & & & 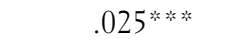 & .005 & -.026 \\
\hline Skin color ${ }^{\mathrm{a}}$ & -.011 & -.137 & -.580 & .021 & -.122 & $-.583^{*}$ \\
\hline Discrimination & .466 & 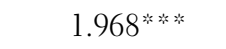 & $2.758^{* * * * * *}$ & .316 & $1.923^{* * * * * * x}$ & 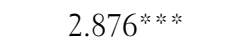 \\
\hline Age & -.011 & .011 & -.019 & -.009 & .011 & $-.026^{*}$ \\
\hline Education ${ }^{\mathrm{b}}$ & .183 & .128 & .187 & .168 & .124 & .151 \\
\hline Household income ${ }^{c}$ & -.035 & -.158 等叔 & $-.113^{*}$ & -.033 & 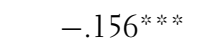 & -.080 \\
\hline Female & .168 & -.036 & .653 & .077 & -.044 & .640 \\
\hline Spanish & -.956 & 1.275 & 1.305 & -1.181 & 1.237 & $1.561^{*}$ \\
\hline Mexican origin & $.902^{2 * * x^{2}}$ & .366 & -.097 & .537 & .321 & .174 \\
\hline $\begin{array}{l}\text { Contacted by public } \\
\text { official }\end{array}$ & .757 & -.039 & -.287 & .701 & -.043 & -.250 \\
\hline Adjusted $R^{2}$ & .148 & & & .154 & & \\
\hline
\end{tabular}

Notes: $* * * * 0.01, * * p<.05,{ }^{*} p<.1, \beta$ is a logit coefficient.

${ }^{\text {a }}$ Skin color: $1=$ Very light, $2=$ Light, $3=$ Medium, $4=$ Dark, $5=$ Very dark.

${ }^{\mathrm{b}}$ Education: $1=$ No formal education; $2=1$ st, 2 nd, 3rd, or 4th grade; $3=5$ th or 6 th grade; $4=7$ th or 8 th grade; $5=9$ th grade; $6=10$ th grade; $7=11$ th grade; $8=$ 12th grade no diploma; 9 = High school graduate-high school diploma; $10=$ Some college, no degree; 11 = Associate degree; $12=$ Bachelor's degree; $13=$ Master's degree; $14=$ Professional or doctorate

${ }^{\mathrm{c}}$ Household income: $1=<\$ 5,000,2=\$ 5,000-\$ 7,499,3=\$ 7,500-\$ 9,999,4=\$ 10,000-\$ 12,999,5=\$ 12,500-\$ 14,999,6=\$ 15,000-\$ 19,999,7=\$ 20,000-$ $\$ 24,999,8=\$ 25,000-\$ 29,000,9=\$ 30,000-\$ 34,999,10=\$ 35,000-\$ 39,999,11=\$ 40,000-\$ 49,000,12=\$ 50,000-\$ 59,000,13=\$ 60,000-\$ 74,999,14=$ $\$ 75,000-\$ 84,999,15=\$ 85,000-\$ 99,000,16=\$ 100,000-\$ 124,999,17=\$ 125,000-\$ 149,999,18=\$ 150,000-\$ 174,999,19=\$ 175,000>$. 